\title{
Sex Dolls in the Swedish Media Discourse: Intimacy, Sexuality, and Technology
}

\author{
Robin Björkas ${ }^{1} \cdot$ Mariah Larsson $^{2}$ (D)
}

Accepted: 9 February 2021 / Published online: 25 February 2021

(c) The Author(s) 2021

\begin{abstract}
Sex dolls are a complex phenomenon with several diverse possible emotional, sexual and therapeutic uses. They can be part of a broad variety of sexual practices, and also function as a sexual aid. However, the media discourse on sex dolls first and foremost concerns how we perceive the relationship between intimacy and technology. A critical discourse analysis of the Swedish media discourse on sex dolls reveals six themes which dominate the discourse: (a) the definition of what a human being is; (b) a discourse on the (technological and existential) future; (c) a social effort; (d) a loveless phenomenon; (e) men's violence against women; and (f) pedophilia. Accordingly, this discourse is very conservative and normative in its view of sexuality, technology, and humanity. Overall, the dominant themes do not provide any space for positive effects of technology on human sexuality, and if they do, it is usually as a substitute for something else.
\end{abstract}

Keywords Sex dolls $\cdot$ Sex robots $\cdot$ Media discourse $\cdot$ Moral panic $\cdot$ Sexual axiom . Sweden

\section{Introduction}

In the past few years, sex dolls have developed not only in appearance and tactile materials, but they have also come to be equipped with advanced technology such as artifical intelligence (A.I.). This development, in its turn, has led to new questions in the social discourse around sex dolls. However, these new questions draw upon previous, similar discourses about the sexual attraction to human-like objects, discourses which include the pathologization and medicalization of the attraction to

Robin Björkas

robin.bjorkas@mau.se

1 Malmö University, Malmö, Sweden

2 Linnaeus University, Växjö, Sweden 
non-living, synthetic human bodies, social conceptualizations of sex and intimacy, and a hierarchy of high and low culture.

Since the nineteenth century, sex researchers such as Bloch, Ellis, and von Krafft-Ebing regarded the sexual attraction to statues, agalmatophilia, as a paraphilia (White 1978). However, not only were such attractions pathologized by these scholars, they also distinguished between them. Bloch, for instance, saw a difference between erotic interest in "statues of exceptional artistic perfection" that had "certain aesthetic motives" (p. 47) and interest in other, lower forms of art. Sexual attractions to lower forms of art could be understood with the same logic that applied to necrophilia, sadism, masochism, and fetischism. In a similar way, Ellis distinguished between people who had an "aesthetic sense" and people who simply were "ignorant and uncultured" (p. 48) and who expressed it by their erotic attraction to statues (Smith 2013).

In today's discourse, such a class distinction remains, although not as explicit as in previous centuries. Also, the use of sex dolls is not described as part of the accepted spectrum of sexual practices. However, it is sometimes justified as a need for people who are lonely or living with a disability. Furthermore, although attraction to non-living yet life-like representations of human beings is not, in fact, defined as a paraphilia (yet there are other classifications in the DSM-V, the Diagnostic and Statistic Manual of Mental Disorders, which might be applicable in some cases), there is an underlying implication in the media discourse about sex dolls that pathologizes users.

The discourse on sex dolls in Sweden expresses a paradoxical relationship to sexuality, and, as we will demonstrate in the analysis, feminist conceptions of patriarchal power relations and men's violence against women are quite dominant in the discourse. In many contexts, Sweden is described as one of the leading nations in the world concerning gender equality, including sex. Since the 1950s, when Sweden introduced mandatory sex education in schools, Sweden has been regarded as a sex liberal nation. Nevertheless, simultaneously, there is a normative view of what kinds of sex are acceptable. As social anthropologist Don Kulick has noted, in Sweden, sex is good, but only good sex, or "socially approved, mutually satisfying sexual relations between two (and only two) consenting adults or young adults who are more or less sociological equals" (Kulick 2005, p. 208).

This makes the Swedish media discourse on sex dolls particularly interesting to look more closely at, in order to discern whether sex liberal and feminist understandings of sex dolls underpin several of the assumptions and expressions in Swedish press. Sex dolls have a special position in social discourses since they, as lifelike, synthetic human representations, evoke questions and anxieties concerning human relationships as well as the relationship between sex and/or intimacy and advanced technology. The purpose of this article, therefore, is to study media articles and debates specifically under these conditions in order to reveal and question some of the dominant norms about sexuality and intimacy in relation to technology in Sweden today.

Accordingly, we wish to address the following questions:

- how Swedish media discusses sex dolls as a phenomenon, 
- how it makes sex dolls comprehensible to the public, and

- how it conveys individuals' social and sexual experiences of using sex dolls during a recent ten-year period (2009-2019).

We do so by conducting a critical discourse analysis, informed by Rubin's theory of sexuality (1984) as well as gender theories, mainly on masculinity. Also, we place our analysis within the context of Sweden, which has a reputation both for gender equality and for sexual liberalism.

\section{A Few Words on Terminology}

Ferguson (2010) defines the sex doll as "any object replicating an ideal object of lust with the necessary apertures or attachments to allow genital penetration" (p. 9). This can be understood as a material representation of the human body for sexual purposes, thereby distinguishing between sex toys which represent limited parts of the human body and the sex doll which recreates the whole body (Döring and Pöschl 2018). Taking our inspiration from Knafo and Lo Bosco (2017), we have chosen the words "synthetic" and "organic" to distinguish between sex dolls/sex robots and living human beings. Although this might seem as objectifying human beings, the use of "synthetic" encompasses both the experiences of (some) of the users of sex dolls, to whom the sex dolls represent much more than just a doll, and the increasing proximity between dolls and humans through technological development. As sex dolls become more "life-like", they at once challenge our ideas of human essence and are more firmly entrenched in the "uncanny valley" of life-like but inanimate representations.

The use of the word "synthetic" risks eradicating the difference between sex dolls and sex robots, but there is a point for us in that risk. Sex robots have some ability to move and also sometimes a certain amount of artificial intelligence, whereas sex dolls, without such mechanisms, are passive (Danaher 2017b). However, the word sex dolls often ecnompasses both dolls and robots, and in the discourse about dolls and robots in Swedish media, they are often conflated and discussed in the same way. Therefore, in this article, we have not made any particular distinction between the two and by referring to dolls and robots as "synthetic" we avoid using the word "dolls" for robots.

Throughout, we have described the sex dolls as they have been framed in the media articles we have studied, as women (or men, or children, in such cases), rather than cisgender women. This is because a sex doll-or any doll, for that matterdoes not have a subjective experience of its own gender.

\section{Previous Research}

In a scoping review, Döring, Rohangi Mohseni and Walter examine 29 publications (of which 17 are peer reviewed) on sex dolls and 98 publications (of which 32 are peer reviewed) on sex robots, published between the years 1993-2019 (Döring et al. 
2020). Most of these focused on ideological, philosophical or legal matters, which means that clinical studies are almost non-existent. The lack of empirical knowledge has as a consequence that the possibly positive effects of sex dolls ("e.g. utopian visions of improved sexual satisfaction and overall happiness") as well as the negative effects ("e.g. dystopian visions of dehumanization, objectification, and isolation") are basically speculation (Döring et al. 2020).

Acknowledging the uncertain grounds for knowledge, Blizzard addresses the need for awareness and vigilance in relation to the potential development of sex dolls in the future (2015). She asks "how do individuals balance sexual freedom to choose a doll as a companion with the potential cultural implications of further entrenching sexual inequalities?" (Blizzard 2015, p. 75).

Nonetheless, there are some studies that examine the uses and functions of sex dolls. For some people, the sex doll is no more than a sex toy among other sex toys. It has no particular social, psychological, or cultural value that distinguishes it from for instance a dildo or an artificial vagina (Döring and Pöschl 2018). For others, sex dolls may respond to needs within relationships and sex. Sex dolls can fulfill an emotional need and be perceived as a partner in an emotional relationship (Knafo and Lo Bosco 2017). Knafo and Lo Bosco (2017) explain this emotional attachment using Winnicott's theory of transitional objects, that is, that the sex doll helps its organic partner to get in touch with their creativity, emotional life and to find a sense of security in a prejudice-free environment.

A fetischism related to sex dolls is ASFR, Alternative Sexuality Fetish Robots, that involves a sexual attraction to robots. According to Devlin (2018), there is a difference between those who prefer ASFR and those who prefer dolls (and call themselves iDollators). ASFR does not concern a sexual interest in technology or a search for the perfect woman per se, rather it concerns the possibility to control the sexual situation by programming the robot (de Fren 2009).

One aspect of sex dolls which is often highlighted in the public discourse pertains to sex dolls representing children. The academic discourse on child sex dolls is in many ways similar to the one on "grown up" sex dolls, including discussions about how they blur the distinction between doll and real person as well as moral and legal discussions, asking for actual legal prohibition (Maras and Shapiro 2017). Studies on child sex dolls often emphasize that the mere thought of abusing a child (regardless if it is a living child or a synthetic doll) is so morally despicable that it should make it worthwhile to discuss a general prohibition on child sex dolls (Danaher 2017a). With support from other studies, Maras and Shapiro (2017) argue that there is a correlation between child pornography, which according to Maras and Shapiro includes child sex dolls, and an increased risk of actually committing child sexual abuse.

In other words, a sexual attraction to sex dolls can also combine one or several other sexual interests and/or identities. This, in turn, opens up a significantly more complex understanding of the phenomenon. Furthermore, although sex may be the primary purpose for the user of a doll, other functions are common as well, found in more than $80 \%$ of cases (Ferguson 2010, p. 237).

Moreover, there is a relatively recent technological aspect to sex dolls. New technology is often met by social anxiety in media and in society in general, in particular 
when technology encroaches on spheres such as emotions, intimacy, femininity, and childhood. Modern technical solutions challenge traditional ideas about how society is constructed and supposed to work, which leads to an anxiety about new technology and a dismissal of technical solutions as secondary and/or problematic (Lindgren 2007).

Scholars have observed that academic literature rarely discusses potentially minor or ambivalent effects of sex dolls and sex robots, but rather make an either-or distinction where effects may be good or bad but are always major. This can be understood as reflecting the general, public discussion about sex dolls and sex robots in media today (Döring et al. 2020; Harper and Lievesley 2020).

As many studies primarily focus on ideological, philosophical, or legal aspects of sex dolls, scholars have also called for studies around "public debates about and media representations of sex dolls and sex robots" (Döring et al. 2020) as well as "social attitudes and responses to sex dolls and robots" (Harper and Lievesley, 2020). Döring and Pöschl (2019) have done a content analysis of both fictional and non-fictional media representations of intimate human-robot relationships (during the period 1927-2014). In their study, they revealed "stereotypical gender roles, heteronormativity and a focus on sexual versus emotional intimacy" (p. 665) as their main findings. This study is another attempt to do a medial analysis, though providing a critical perspective on the Swedish, public media discourse on sex dolls (including sex robots).

\section{Theoretical Perspectives}

Gayle Rubin's theory of the six axioms of sexuality from 1984 will be used to analyze the discourse on sex dolls. According to Rubin, a radical theory about sexuality has to be able to identify, describe, explain, and condemn erotic injustice and sexual oppression. Also, she claimed that such a theory needs to be built on detailed descriptions of human sexuality in contemporary society as well as through history in order to understand fully how sexuality is constructed and valued. This is particularly relevant in the case of sex dolls, because sex dolls are not a recent phenomenon, even though they are constructed as such in the current media discourse. In addition, Rubin's theory sheds light on the causes of why some sexual practices are regarded negatively and others are celebrated.

The six axioms are sexual essentialism, sex negativity, the fallacy of the misplaced scale, the hierarchical system of sexual value, a domino theory of sexual peril, and the lack of a concept of benign sexual variation. These axioms are interrelated and all of them are relevant to the analysis, but the most clearly prominent in the discourse on sex dolls are sexual essentialism-that sex dolls are not human, which either applies in a positive context because sex dolls are regarded as a sexual aid, or in a negative one, where men are not turned on by "real" humans-and the domino effect, which contributes to the question of "where will this lead?".

In the media discourse on sexuality in general, classic and modern sex research is often omitted, which is a problem. Not because sex research is unburdened by contemporary norms and values, but because sex research includes perspectives 
that view sexual variation as an existing phenomenon rather than something that should be shunned. When Rubin calls for a "radical theory of the politics of sexuality", such a theory would include classic and modern sex research that attempts to relate to sexual variation as a something which needs to be studied and understood as it exists. Rubin contrast this with the, in her opinion, less useful psychoanalytic or feminist perspectives that are often applied to discourses on sex and sexuality, but such a research-based approach can be contrasted as well to media discourses which tap into general ideas about morality (Rubin 1984).

Rubin developed a model of circles to describe the sexual value hierarchy of accepted sexual practices and un-accepted ones. In the Charmed Circle, the inner circle, Rubin placed heterosexual, monogamous, coupled, reproductive sex within relationships or preferably even marriage, without manufactured objects, pornography, or transactions of money involved and taking place indoors, confined to the bedroom (Rubin 1984). As a contrast, the outer circle or the Outer Limits, formed the place for what society regards as abnormal, unnatural, and damned: promiscuity, cross-generational sex, homosexuality, BDSM, sex for money, sex taking place outdoors, and also including the use of manufactured objects and/or pornography. For our purposes, the sex that makes use of manufactured objects is the category most relevant, but the category of cross-generational sex also has bearing on some of the media discourse on child sex dolls.

In addition, the use of sex dolls often evokes associations of childish play and make-believe. As much of the media discourse focuses on male users of sex dolls, a connection is made between men and childishness. Men with childish behavior are presented as highly problematic. The childish man has no place within hegemonic masculinity, he can even be perceived as dangerous and volatile. Masculinity and gender therefore play an important role in how the media discourse understands sex dolls as objects of desire and as partners in intimate relationships. The ideal man, ostensibly, should rather have a mature couple-relationship with a member of the opposite sex, mature being the key word in defining both masculinity and the relationship. In opposition to this is the immature man, who refuses to grow up and take responsibility. Although there is a loophole in the construction of masculinity for men to be childish or immature (e.g. "boys will be boys"), this loophole relies to a great extent on the individual man's established position within hegemonic masculinity.

Another gender aspect to the phenomenon of sex dolls is the feminist understanding of sex dolls as a reification of women. One of the most prominent scholars against sex dolls is Kathleen Richardson, whose research areas are robots and AIethics. Richardson has founded the organization "Campaign Against Sex Robots" (CASR) with the aim of prohibiting sex robots. According to Richardson (2015) and CASR, the use of sex robots constitutes a threat to society because, they argue, that men who have sex with sex robots develop a sense of women as things. CASR thus argues that such men may treat living, organic women based on their insensitive experiences of sex dolls. However, the feminist analysis of sex doll use is not homogenous and there are other views (Devlin 2018).

In "Thinking Sex", Rubin made an argument against (anti-pornography) feminism, claiming that "the relationship between feminism and sex is complex" (1984, 
p. 165) with sex-positive feminism in conflict with an anti-pornography feminism that Rubin described as anti-sexual. This has been interpreted as anti-feminist, but in a reflection on her article twenty-five years later, Rubin makes it clear that she regards her work as "within the best traditions of feminist discourse" (Rubin 2011, p. 37).

Finally, the concept of the "uncanny valley" provides an evocative understanding as to how, exactly, society perceives sex dolls as controversial. The concept of the uncanny valley was introduced in the 1970 s by the Japanese robot researcher Masahiro Mori. By this concept, Mori could point to the moment when the empathy for a humanoid robot or another lifelike copy would instead turn into uneasiness and even loathing. As long as the robot or lifelike copy is reasonably similar to a human, empathy is the strongest emotion, but when the likeness becomes too striking, it evokes creepiness and disgust. This is the uncanny valley (Mori et al. 2012). Somewhat simplified, Mori defines three variations of how such figures are perceived: those that evoke little or no empathy such as industrial robots or toy dolls; lifelike copies that belong within the uncanny valley and thereby evoke creepiness and disgust, such as prosthetic hands, zombies, or dead people; lifelike copies that have such a high cultural value that they are comparable to healthy organically living human beings, like the puppets used in the traditional Japanese bunraku plays. Bunraku puppets are life-like, yet belong within a clearly marked cultural context with a particular significance in that context (Mori et al. 2012). The uncanny valley can, in its turn, be related to the breakdown of boundaries brought to the fore in Donna Haraway's The Cyborg Manifesto (1985) as the cyborg-mechanical-human/ human-mechanical-also may invoke a dissolution of the binaries taken for granted in society.

As a concept, the uncanny valley is useful because it explains the uneasiness that can occur when a lifelike copy becomes too lifelike and thereby fails to evoke the empathy necessary for a successful human-robot interaction (Mori et al. 2012). Nonetheless, it should be noted that the theory of the uncanny valley seems to be subjective, depending on different people's personal experiences and socio-cultural contexts (Kätsyri et al. 2015).

\section{Material and Method}

The material that was used in this study was found through Retriever Research, a Nordic digital news archive which collects news from print as well as digital media since the 1980s. The first search yielded 900 results, although several of these were from news bureaus and thereby the same text recurred in several different contexts. Accordingly, in reality, there were far fewer texts to include in the study. Inclusion criteria were (1) the mention of sex doll or sex dolls as a concept, (2) the main focus of the text was sex dolls and/or sex robots, and (3) that the text was in Swedish. Exclusion criteria were (1) only a brief mention of the phenomenon, (2) the text was too short (four to five sentences or less), (3) the text was too similar to other texts (when a text was reproduced from a news bureau's original, it was only included once), (4) the written text was subordinate to audio or video files, and (5) that it 
was not in Swedish. Ultimately, 98 texts were included in the study: opinion pieces, essays, readers' opinions, chronicles, op-eds, news articles, and features.

This study uses a critical discourse analysis of written media texts from various Swedish news media, foremost newspapers. The purpose of critical discourse analysis is to analyze power structures by connecting dominant social discourses with social phenomena, in this case sex dolls. Critical discourse analysis studies texts at three levels: the text itself, the discursive practice, and the social practice (Winther Jørgensen and Phillips 2000). On the first level, the text, we discerned significant categories, which then organized the analysis, for instance "liberation through sex dolls" or "patriarchal structures". Furthermore, words, phrases, and sentences were organized under the headings of ethos, transitivity and modality. Phrases that constructed identity were placed under ethos, like for instance "rail-skinny female doll bodies with enormous breasts". Several of the words and phrases under this heading were value-laden. Under transitivity, how subject and object are connected for an ideological effect, we placed phrases such as "women should not be made in a factory" or "doll brothel hopes for soccer world cup". Modality, which conveys how much the speaker or writer agrees with something in their statement, was used for phrases and sentences like "The brothel owner tells the Finnish newspaper Iltalehti that it is all about 'helping people' satisfy their sexual needs, in particular those who have difficulties with sex with other people" (Wilson 2018). Here, the use of quotation marks clearly signals the distance of the journalist to the statement of the brothel owner (Winther Jørgensen and Phillips 2000).

By reading the articles in relation to previous research and Rubin's six axioms, as well as by relating the themes and headings to the axioms, we identified six themes in the discourse: the definition of a human being; a discourse about the future; a social intervention; a loveless phenomenon; male violence against women; and pedophilia.

Concerning discursive practice, we have mainly looked at the occurrence of interdiscursivity (the discourses that a certain text is built upon). According to Fairclough (1995), a high degree of creative interdiscursivity is often a sign of change or a will to change, whereas a lower degree of interdiscursivity signals constituting and reproducing elements of an already dominant order of discourse. Social practice is included because text and discourse cannot exist by themselves, but are included in a wider and complex context (Winther Jørgensen and Phillips 2000). To analyze the social practice, usually an additional theory is needed that does not come from the text itself. Rubin's theory functions as a critical counterpoint that questions dominant social norms about gender, age, and sexuality in Western society.

\section{Analysis}

The analysis of the 98 media articles showed that the discourse on sex dolls in general does not really concern sex dolls in themselves, as a phenomenon, but rather the juxtaposition of intimacy and new technology. This is quite clear through the six previously mentioned themes identified in the discourse: the definition of a human being; a discourse about the future; a social intervention; a loveless phenomenon; 
male violence against women; and pedophilia. At the core of these themes lies a fear of what technology will do to "human" intimacy.

\section{The Definition of a Human Being}

The question of what defines a human being is central and recurring in the different articles. Two primary models for explanation function both to separate and to bring together humans and dolls. The first one focuses on sex dolls as non-human, by emphasizing for instance "jerky movements", "female doll bodies, skinny as rails" and "super tight holes", making a point of the synthetic woman's very oppositeness of the living, organic female body. In these cases, it is always a woman. At the same time, several of the texts focus on the similarities of synthetic and organic bodies. Words such as "natural", "super realist" or even "hyper realist looks" occur frequently in the description of the dolls. Again, it is primarily the bodily characteristics of the dolls that are foregrounded, such as when one journalist writes that "Samantha has high cheekbones, green eyes, and a G-spot" (Fjeldstad 2016).

In this juxtaposition of organic human versus synthetic doll, the experience of the uncanny valley is clearly at work: on the one hand, the dolls are very similar to humans, but on the other hand, they lack the vital characteristics that make up organic life. They become uncanny because they are too life-like without actually being alive, and they lack a cultural acceptance or social ritual which would contain them like for instance the bunraku puppets, for which there is a clear demarcation between stage and audience.

In the articles, the writers seem always to have to relate to how sex dolls are supposed to be understood. Should the sex doll be regarded as a doll, that is, a sex toy, is it a human, or is it something in-between or even both? In one article, the interviewed person is critical to the fact that the sex dolls are marketed as substitutes for women rather than the sex toys she regards them as (Jones 2019). As an in-between, the doll becomes the focal point for disgust and uncanniness. Regardless of the perspective of the writers, this relationship seems to affect their descriptions of sex dolls as a form of lifelike copy. Interestingly, in the same interview, focus is placed on the face, rather than on the body: "Just because there is, around the technology, a female face that, according to norms, is attractive, expectations are raised" (Jones 2019, p. 24).

However, the definition of a human being (or of a woman, which is most common) does not only confine itself to the discussion of synthetic versus organic bodies. The media discourse follows a heteronormative logic, emphasizing sex dolls as a heterosexual phenomenon. Implicitly, the sex doll relation always concerns an organic man and a synthetic woman. This presumption is based firstly, on an idea of the heterosexual (monogamous, reproductive, mutual) relation as the ideal relation (cf. Rubin 1984), but since one of the parties is synthetic, the ideal is twisted. Secondly, it is based on a notion of a sexually active male (organic) and a sexually passive woman (synthetic). Very little expressive ethos is used when describing synthetic men and there does not seem to be any clear and recurring use of modalities and transivities within this theme. On the one hand, this makes it difficult to analyze 
these few and brief mentions of synthetic men, but on the other, the absence in itself defines the synthetic woman as heterosexual in reaction to the men she is supposed to please.

Accordingly, this theme extrapolates the idea of what it means to be human beyond the purely biological and organic. In the discourse on sex dolls, certain expectations of a human are made clear: a human is heterosexual (unless otherwise explicitly noted). This relation to the norm might bear witness to a more general perception in society, but it can also be understood as a reproduction of normative ideas about relationships, sexuality, and love by the media.

\section{A Discourse About the Future}

Secondly, the articles concern the possibilities and threats of technical development. These are often described in conflicting ways, either with a focus on a dreary, industrial environment in an Asian factory somewhere, or small time entrepreneurs whose fortune has depended on advanced technological development; "The plastic women hang in a line in the factory. A man in a grey workers' shirt takes them down one at a time, and listlessly paints the buttocks with beige paint." (Kierkegaard 2018).

The articles begin with the recurring tropes of how modern sex dolls are a result of recent technical development and of the conditions of production. Sometimes sex dolls are described from a more liberal viewpoint, that claims that sex dolls are just one type of sex toy among many others. More often, however, the articles regard these dolls as the product of patriarchal structures in the technical development and that sex dolls with AI (i.e. sex robots) therefore are the most prominent example of the misogyny of society. This perspective can be found for instance in the common usage of negatively charged ethos such as "slavery", "exploitation of the female body", and "gallopping AI-technology" in several of the articles. In particular, the phrase "gallopping AI-technology" evokes the domino theory of sexual peril, as "gallopping" implies something happening very fast and outside of our control (Rubin 1984).

The domino theory is very inherent in the media discourse on sex dolls in general, suggesting that we need to stop this development before it gets out of hand. One op-ed article, written by prominent figures within the Swedish women's movement, explicitly highlights the possibilities and threats of technological development by juxtaposing what the sex doll industry does (letting itself be run by the sex industry) with what technology should be doing (make life easier and more gender equal). Referring to Kathleen Richardson, they claim that the exploitation of the female body through new technology dehumanizes women and thereby justifies slavery (Berglund et al. 2019).

Many of the writers exclude a subject, that is agency, in their critique of sex dolls. Regardless of whether such an omission is conscious or unconscious, this is an effective way of disregarding the positive aspects of modern technology, and simply concentrating on risks. Although sex dolls are defined as the result of a negative development in society, the articles convey a sense in general that technology should not include the sex industry at all. In the discourse about the future, conditions of 
production and advanced technology are not the only focus. Many writers return to the idea about the continuing technical development as such. For instance, sex dolls and sex robots can be ordered online "with a mouse click", a phrase that brings attention to how technology and social issues come together with the widespread distribution of the internet and an increasingly globalized world. The concept of "a mouse click", which in many cases is used to promote how easy something is ("pay your bills with a mouse click"), has in these cases a negative association that implies how close and easy something dark and sinister lurks. The same phrase is often used in anti-porn messages.

Again, there are parallels to be drawn to the uncanny valley (Mori et al. 2012) and how society views sex with a synthetic yet lifelike copy. A dildo or an artificial vagina could of course be classified as a kind of lifelike copy, but at the same time they only exist without a body attached to them. Since they do not have a body, there is nothing to project the existence of a soul onto. A sex doll, however, through its similarity to an organic person, evokes thoughts and ideas about living things in a different way and is therefore much easier to identify with. In Western society, which can be described as sex negative (Rubin 1984), new technology is thus highlighted as a threat, rather than as a possibility: if there would be a general access to sex dolls, well, that would mean that new technology would be used to reproduce sexual fantasies and thereby sexual practices which are perceived of as undesirable in our society. New technology is in this manner held accountable for a sometimes explicit, sometimes implicit, threat with a worst case scenario of allowing sex dolls the sexual and/or emotional use they in reality do have for several people. This notion can be connected to Rubin's idea of the domino theory of sexual peril (Rubin 1984). The only possible exceptions are in those cases when sex dolls function as social intervention.

\section{A Social Intervention}

One of the recurring elements in the articles is lonely men. In these cases, sex dolls are described as a way to explore their sexuality as well as a "solution" to a non-existing couple relationship. In this theme, there are two main versions: one is that sex dolls, like Masters and Johnsons therapeutic work with sex surrogates (Maier 2013), could contribute to helping people with sexual and/or social difficulties by giving them an opportunity to have positive sexual experiences which would encourage them in their social and sexual life. In this version of the theme, favorably charged words such as "explore", "safe", and "without stress", are used. Also, subject and object are more in tune with one another in texts that belong within this theme, which could be connected to a more liberal view of a diverse sexuality. However, this should be understood in the context that the writers themselves avoid explicitly aligning themselves with this discourse, but rather relate what others have said. Sometimes they even seem to present quotes in a way that undermines the messages, such as for instance "'To be allowed to explore your sexuality in a safe, stress-free, non-judgemental environment where no one is exploited'-that is how the new brothels market their services" (Torstensson 
2019). By putting a phrase within quotation marks, a journalist can make it sound suspect, such as in this sentence "The brothel owner tells the Finnish newspaper Iltalehti that it is all about 'helping people' satisfy their sexual needs, in particular those who have difficulties with sex with other people" (Wilson 2018).

In the other version of the theme, the point is made that sex dolls are not for anyone, but first and foremost for two sub groups of lonely men: men with intellectual disabilities and older men who have lost a life partner. In many of the texts, the image painted of the relation between a sex doll and a living person conveys that it is not a "true" relationship, but rather a substitute for something else, a substitute that falls outside of the scope of expectations of a grown person and their sexuality. Such cases confirm a sexual value hierarchy in which "marital, reproductive heterosexuals are alone at the top erotic pyramid" (Rubin 1984, p. 151) and these other men- "failed" in a sense-have to console themselves with a substitute. In the following quote, there is an emphasis on how the emotions experienced in relation to a sex doll are with a "factory-made, purchased partner": "The enthusiasts of the industry often point to examples of elderly whose partner has passed away and who socialize with a robot to manage their grief, or lonely people who get the chance for a new kind of love with a factory-made, purchased partner" (Kierkegaard 2018). Rubin (1984) claims that heterosexuality is arranged in a hierarchical system where certain forms are more privileged than others. Some sexual acts are normatively significant to men, whereas others are defined as deviant. Thus, heterosexuality must always express itself and be performed within an expected form in order to also fall into the norm of what is accepted. Even simply being without an active sexual relationship or, like in this case, have sex with a synthetic woman, is to fall outside of hegemonic and heternormative masculinity.

The fact that certain masculinities are privileged (cf Connell 2005) in relation to others stand out in those articles that discuss how sex dolls can be used therapeutically to train empathetic abilities. In such articles, although sex dolls are used with a clear therapeutic function as transactional objects (Winnicott 1971), the use of them is still consided deviant and the men who need such therapy are regarded as failing in their masculinity. One article relates a medical doctor specialized in sexual medicine, who explains that many of her patients do not look for sex with the sex dolls but rather need someone to talk to. In the same article, she is also quoted as saying that sex dolls and robots are a symptom of a "pornified" society, and that she is thus hesitant to use them (Häggström 2017).

In comparison to Rubin's (1984) sexual value hierarchy, it is clear that sex is something which is supposedly between two human beings and not between an organic human and something which hovers between the definition of a sex toy and a synthetic human, threatening to dissolve the relatively stable boundaries between sex toy and human being. Accordingly, sex dolls are regarded as the result of a sex negative and misogynist time in history for which explanatory models like a "pornofied society" and internalized misogyny to a large extent are the only recurring explanations to the need for sex dolls as well as the use of dolls for some kind of therapeutic purpose. In this context, it should be noted that the media discourse on sex dolls does not focus on sex with sex dolls as an alternative within the normal 
variation of human sexuality, but rather as a final alternative when all other options have been tried with no results.

\section{A Loveless Phenomenon}

The fact that sex dolls are described as a loveless phenomenon is strongly tied to the previously addressed theme of "a social intervention". Both of these themes imply a sense that men "opt out" of something (or rather someone) from the Charmed Circle. In this theme, there are two interrelated sub categories. One concerns sex with sex dolls as an incomplete sexual practice and/or orientation, deserving of criticism from society. The other one concerns a normative view of how heterosexual, organic relationships ought to be. With ethos such as "substitute", "without interest", and "how to satisfy women", articles emphasize that sex dolls are synthetic. Even when alternative opinions are allowed space in the articles, it is usually in a way that privileges those voices that agree with the main narrative of the article. For instance: "Opinions are divided - the A.I.-enthusiast David Levy claims in his book 'Love and Sex with Robots', that such relations can be seen as equal to human interaction, in particular if an A.I.-unit is intelligent enough to develop together with its partner. Levy's critics, among them the philosophers Sven Nyholm and Lily Frank, object that Levy refers to something imitating human relations and avoids the issue of love between equal partners" (Tapper 2018). They are devalued as a kind of second class sexuality because relationships with sex dolls do not involve two human beings who are mutually devoted to one another. In these articles, narratives that bear witness to relationships with synthetic women-coupledom as well as weddings-as unsound because the relationship between human and synthetic person cannot be founded on an expressed, reciprocal love. According to Rubin's axiom of the lack of a concept of benign sexual variation, there is only a narrow window for accepted sexual variation and the variation that includes a synthetic person is not one of them.

Here, in contrast to the previously mentioned themes, focus does not lie on the social difficulties of men, but rather on the inadequate emotional abilities of the synthetic women. With heavily emotionally invested words such as "healthy relationships", "in the real world", and "the fantasy bubble of the boy's room", it becomes apparent in different texts how the writers expect an authentic relationship to be, but most of all that it should always concern an equally mutual organic love and be founded on organic sex. To maintain the undesirability of certain sexual behaviors, in this case "loveless" sex with synthetic women, they are punished by being stigmatized by various social, medical, and psychiatric discourses. According to Rubin (1984), this is an efficient form of sanction against those who wish to engage in such sexual practices.

In one of the articles, a psychologist comments on a story of a Japanese man and his love relation to a sex doll, claiming that "children animate, that is make alive, dolls, cuddly toys and other things. This is an important part of playing and helps children develop empathy, caring, and different roles. But continuing with this behavior is weird" (Hansson and Grahn 2016). The quote illustrates the notion that when a child is playing it is not only fine, but also beneficial, whereas when a 
grown up man plays with dolls, something uncanny occurs. The fully grown male who refuses to grow up and mature evokes both ridicule and fear. To become a man, to be a man, means to lay off childish things, a convention that is as old as the Bible: "When I was a child, I spake as a child, I understood as a child, I thought as a child: but when I became a man, I put away childish things" (1 Corinthians 13:11). Although Rubin's text concerns itself with religious taboos that have influenced sex laws, the Bible's denouncement of childishness can be regarded as an early example of a still very strong societal norm about the necessity to grow up. There are sex laws derived from religious taboos, but, as Rubin points out, these "were aimed at preventing the acquisition of the wrong kinds of affinal partners" (Rubin 1984, p. 151). Here, it is rather a question of immature desires and not "proper" romantic love. The implications of a boy in a man's body provoke the comments about the "boy's room": "Already today there are men who have relationships with and even get married to sex dolls or digital girlfriends. Men who never grow up, but remain in the phantasy bubble of the boy's room far into their middle age" (Tapper 2018). A child who plays with dolls has a rich imagination; in contrast, as the quoted psychologist describes it, a grown man with a sex doll is rigid and lacks empathy.

Young men are expected to break away from the boy's room in order to mature and grow up and gain their own ordered homes and families (Reid 2012). The image of the immature boy and his teenage room functions as a productive mental picture to use when writers discuss the sexual attraction of sex dolls and recurs in several of the texts that discuss men and sex dolls. What many of these critical writers miss when they make use of this image is that they reproduce and reinforce hegemonic masculinity as the one true masculinity.

\section{Men's Violence Against Women}

An overarching theme that seems to appear in most of the articles is whether sex dolls should be understood as a part of or a result of the objectification and oppression of women in society. In the discourse about sex dolls and men's violence against women, strongly value-laden words and phrases like "objectification", "sexualization", and "degradation". This theme includes a discussion of the image of women that sex dolls are understood as the result of. The largest issue in this theme, however, is not so much about the objectification of women per se but more often the effects for organic women of men having sex with synthetic women. However, in some cases, sex dolls are used as one example of many of a symptom of men's problematic relationship to women, such as here: "And I really hope that 2019 is the year when we can start to talk about men's sexuality instead of all the short-cuts around it. Like the sex dolls and the brothels and the violent porn and all other harmful things that some men devote their time to in the sexual area and that rarely are questioned" (Thomasson 2019).

In several of the texts, the synthetic woman is presented not only as a threat but as a direct danger to organic women, through explicit and implicit allusions that the line between sex doll and living woman risks being erased. Even texts that challenge such a model still have to relate to this theme in one way or the other, although 
they do not accept it. The theme of violence against women builds upon an ideal of egalitarian power relations, which the (female) synthetic human threatens. However, this ideal is, precisely, an ideal, which is well worth striving for in human relationships but may not be easily transposed to relationships between organic humans and synthetic bodies, where the synthetic counterpart in no way can reflect on their own situation. As Steven Angelides has pointed out, power relations are always complex, never fixed, and rarely equivalent (2019). The urge to impose a human, ethical agenda on a human-synthetic relationship speaks of the unease evoked by the uncanny valley and the blurred boundaries between human and machine (Mori et al. 2012; Haraway 1985), but does not really address the complexity of sex dolls as a phenomenon. Instead, in Rubin's words, it conjures the domino theory of sexual peril (1984), that is that a clear limit must be upheld in sexual issues in order to separate order from chaos. This discursive theme thus underlines and enforces the previously mentioned argument that sex dolls need to be condemned regardless of whether they are seen as a sex toy or as a synthetic woman.

Moreover, relationships with sex dolls are associated with another kind of sexual practice that falls outside of the expected framework for love, namely transactional sex. Are sex dolls simply a part of the technological development towards more and more advanced sex toys or are they rather a kind of technological extention of sex purchases? The latter is a highly relevant question since several writers, regardless of their actual attitude to the phenomenon in general, attach words related to harm or harm reduction to their discussion about sex dolls. In the previously mentioned op-ed, it is one of the most pressing issues: "For twenty years, Sweden has had a legal framework that penalizes sex buyers and that has decreased the demand for prostitution. The sex purchase act has had a clear normative effect and influenced how we regard sex purchases and women's bodies. Now Sweden must take the next step and dare to address the current technological development that is driven by the sex industry at the cost of real women and girls" (Berglund et al. 2019).

This probably has to do with the sexual axioms that influence Western society as a whole, but it can also be understood in relation to Sweden's particular position in the discourse on transactional sex. In Sweden, it is illegal to purchase sexual services but not to sell them. This is usually referred to as the "Swedish model", a model which has been adapted in some other countries, for instance Norway, Iceland and Canada. Organizations such as WHO and Amnesty have spoken out in favor of a decriminalization as a way to enforce sex workers' rights and improve their lives, whereas the Swedish model is based on an idea about how sex purchases express and reinforce men's violence against women, since the act of buying implies a reification of another human being. Therefore, in Sweden, the discussion about transactional sex is highly politicized and the discourse does not open up for alternative interpretative models.

In addition, the discourse raises the expectation that individuals need to make a stand and have an opinion in the matter of men's violence against women. This is done by quoting users or brothel keepers, who are framed as individuals without any professional knowledge about the structure and psychology of sex dolls, and psychologists, who speak from a position of authority regarding which sexual practices are good and which ones are bad. Sometimes, articles refer, somewhat fleetingly, to 
research and more rarely to a specific scholar. One of the few scholars who is actually quoted in these articles is Richardson (2015), who is a professor of ethics and culture of robots and AI. Richardson is one of the front figures of Campaign Against Sex Robots (CASR) and claims that sex dolls are a result of objectification, sexualization, and in its extension, men's will to dominate women in society as a whole. As only a few of the 98 articles in this study offer any other research-based explanatory model, the impression made by them is that any kind of commercial sex, including sex dolls, is detrimental to women's rights in society. As Rubin observed: "Much political writing on sexuality reveals complete ignorance of both classical sexology and modern sex research" (1984, p. 154). In fact, all the themes suffer from a kind of feedback loop, through which the same "experts" state basically the same thing again and again in different articles and thus reinforce their message through repetition, instead of engaging with new research.

In general, media not only produces but reproduces existing ideas about sex dolls as well as men's violence against women. In this manner, the article writers also produce an essentialist and hegemonic image of how human sexuality should be. This is clear from the very limited number of "proponents" and "opponents" that keep appearing in the articles (of which Richardson is one of a few), and the crossreferencing between different articles that occur.

\section{Pedophilia}

The one theme that differs most from the others discussed here is the one about child sex dolls and adult users' interest in such dolls. Like the adult sex dolls, child sex dolls are described as realistic, but in contrast to the adult sex dolls, their looks are almost only addressed in relation to their (short) stature: "One of the dolls is only $148 \mathrm{~cm}$ tall, which brings to mind sexual abuse of children. According to the owner, they have followed EU's regulations that stipulates that child sex dolls are shorter than $140 \mathrm{~cm}$ and that they have no intentions whatsoever of having pedophiles as customers (Vickhoff and Andersson 2018). The avoidance of describing other, possibly childlike, characteristics, is likely due to the sensitive issue of the sexual child. Historically, sexual abuse of minors was reinterpreted in the 1970 and 1980s, creating a situation in which, on the one hand, child sexual abuse was understood as (male) abuse of power and children's powerlessness, and on the other, children's sexuality, especially as something positive, was erased as a possibility, resulting in the "impression that childhood sexual activity itself is being condemned" (Angelides 2019, p. 51). Thus, even speaking about a sexual child has become impossible, providing an efficient obstacle to any descriptions of child sex dolls in the media discourse.

Accordingly, child sex dolls are clearly associated with their organic counterparts since the view of the sexual child is in risk for being (too) closely related to child sexual abuse. This is emphasized in most of the articles discussing such dolls. That dolls made for sexual purposes hold a special position in comparison to dolls made for CPR-training, toys or mannequins, is symptomatic of the fallacy of the misplaced scale. In relation to child sex dolls, any potential 
further descriptions of their looks and shape (except descriptions of genitalia) are indirectly superflous, since simply the idea of sexual fantasies about children-regardless whether they are synthetic or organic-seems like something completely unthinkable. Swedish child scholar Anna Sparrman has identified a pedophile gaze that does not actually concern the child as a concrete individual but the child as an abstract phenomenon (Sparrman 2014). Accordingly, one of the consequences of society's pedophile gaze is that it affects the idea that if child sex dolls were to be allowed, the domino effects of sexual peril would indeed lead to mass pedophilia and sexual abuse of children. One article refers to a case in a Norwegian court and quotes: "The court is of the opinion that a child sex doll like this one is harmful to society by contributing to attitudes that intend to make sexual abuse of children less troublesome' states the verdict" (TT 2018). This might seem a bit far-fetched, but in fact the fallacy of the misplaced scale as well as the domino effects of sexual peril is consistent throughout the entire discourse on child sex dolls and their users. In relation to pedophiles, this is unsurprising since they belong with "the lowliest of all, those whose eroticism transgresses generational boundaries" (Rubin 1984, p. 151) This can be understood in relation to Angelides' observation that "child sexuality is conceived as premature (play, experimentation, imitation), whereas adult sexuality is conceived of as mature (developed, fully realized, authentic)" (Angelides 2019, pp. 62-63). In addition, the tendency to judge sexuality with a specific measure reinforces this way of thinking, which in its turn leads to the current discussion being influenced by the lack of logic already built into the discourse.

Another illustration of the ambivalent perspective on child sex dolls within this particular theme lies in the many articles which first and foremost describe these dolls negatively by evoking ethical problems or as a kind of treatment for an unwanted sexual orientation. For example, one article, on child sex dolls being sold to pedophiles, refers to a psychologist who "speculates that the dolls-for some pedophiles - can be an outlet for their sexual urge and decrease the risk that they will look for sex with real children. But that applies to far from all. For others, these substitutes can only lead to an increased sense of sexual frustration" (TT 2016). The ostensible domino effect is again called to mind as it seems inconceivable to use a sex doll without reverting to demanding — or even wanting — sex with an organic child. Within this theme, no allowance is given for anything other than a harm or harm reduction discourse instead of asking how individuals with pedophile orientations can live out their desires without harming anyone.

Furthermore, child sex dolls are not only a moral problem but also a legal one. Several of the articles point out that customs in various countries have confiscated child sex dolls, interpreted as breaking with child porn legislation. These articles quote or refer often to a discourse, a researcher or, more generally, to "research", posing questions as to whether child sex dolls can be helpful in limiting the prevalence of sexual abuse of children. At the same time, there does not seem to be any inclination to discuss the objectives of the current legislation, which in its turn reinforce the traffic in child sex dolls as a stable category of something criminal and therefore also immoral. Due to the horrifying emotional response to the notion of child sex dolls, an open discussion as to whether they might be helpful or dangerous 
becomes impossible. The significance is magnified, in what Rubin describes as the fallacy of the misplaced scale (1984).

Here, too, a kind of feedback loop emerges in the media discourse by which the discourse itself reproduces the dominant pedophile discourse. Again, the discourse confirms itself by the intertextual frequency with recurring quotes, references, and cross-references. As mentioned previously, this tendency is common in all themes. However, in the theme of pedophilia, complex traces of discourses concerning everything from new technology to men's violence against women are perpetuated. Thus, the pedophile theme holds a special position in relation to the other themes. No other theme so clearly repeats itself, reinforced by and reinforcing the strongly negative view that society has on sexuality in connection with children, regardless whether such a connection concerns living, organic children or not.

\section{Discussion}

The media discourse on sex dolls concerns not so much sex dolls in and of themselves, but instead the relationship between new technology and intimacy. This is not surprising, since according to Rubin (1984), the sexual practices included in the "Charmed Circle", only involve (organic) bodies and sex with manufactured objects is positioned among the unaccepted, unnatural practices in the "Outer Limit". Rubin's article is from 1984, and with necessity, some developments have taken place that have slightly altered the sexual value hierarchy and adjusted the positions within the circles. For instance, sex "with manufactured objects" is no longer always considered unnatural or abnormal; in some cases, as with vibrators as a masturbation device for women, it can even be accepted. Nonetheless, in relation to sex dolls, the idea of (organic) bodies versus manufactured objects, the opposition seems to remain.

There is a gender aspect to this which is significant, perhaps particularly in relation to the media discourse in Sweden. In the articles, the place of women in society is often related to and made dominant to the role of the sexual revolution. This means that vibrators - as a means for women to take control over their sexuality and their orgasms - can be regarded in a positive light, whereas sex dolls (who are always constructed as made for the use of men) become an exaggeration of the male sexual desire for an object. Sweden is often described as a role model for gender equality and a feminist country - not least because of legislation connected to such issues such as the Sex Purchase Act and the law against gross violation of a woman's integrity. In addition, there is an unofficial initiative like Reklamombudsmannen, the Swedish Advertising Ombudsman, that is a non-profit organization that models itself on actual, similar official authorities like the Equality Ombudsman, and has had impact by being quoted in magazine and newspaper articles and whose reviews are sometimes reported on in national news programs. This development in Sweden can on the one hand strengthen women's role in society, but at the same time it reinforces ideas about what a woman is and how she should behave, constructing a female role model that stays within the Charmed Circle and relates defensively to the "sexual hierarchy" (Rubin 1984). 
One of the large issues that emerged in this study deals with defining who, or what, a human being actually is. Can the synthetic human (regardless of whether they are a woman or a child) be regarded as something unsettling, "living dead", like zombies, or is the synthetic human instead an acceptable life-like copy, occupying a similar, positively charged, position as the bunraku puppets? The instances of the second viewpoint in the articles are extremely rare, and usually pertain to other kinds of dolls than sex dolls, but the respective positions point to where the article can be placed on the "uncanny valley" diagram. Whether the person attaching themselves to a doll is a grown-up or a child plays into how the relationship is perceived and described. A grown-up (man) who has an animating relationship to a sex doll is understood as childish and immature in a negative way which plays into ideas of hegemonic masculinity.

It should be noted that some themes are missing from the media discourse on sex dolls in Sweden. For one, there is no discussion about race and ethnicity, a conspicuous absence considering that gender is at the forefront in the discourse and that race and gender relations often are intertwined. It can, of course, have to do with a lack of racialized sex dolls in the cases that the journalists report on, but in that case, it is interesting to note that none of them care to point this out. Another, more suspicious explanation, would be that it has to do with a Swedish "color blindness", that is, the Swedish (wrongful) self-perception of itself as a non-racist, ethnically homogenous nation (cf. Hübinette et al. 2012; Hübinette and Arbouz 2019). Another missing theme is that, apart from the distinguishing between child sex dolls and adult sex dolls, there is no discussion about age as a spectrum. Either the writers take it for granted that all adult sex dolls adher to conventional ideals of (feminine) beautythat is slimness, symmetry, and youth-or the idea of mature or elderly sex dolls may simply be too "sick" and "way out" (Rubin 1984, p. 154) for the journalists to even conceive of. Conventionally, the process of aging coincides with a process of desexualization, in particular and often earlier for women. However, "mature" exists as its own category on porn streaming sites and "granny" as a search term. As absences say at least as much, if not more, about a society's discursive constructions of sexuality, intimacy, gender, race, age, and so on, these missing themes would be interesting as topics for future research.

The articles in this study are all part of a general, public news media, which means that they are written with a general readership in mind. Accordingly, it is not surprising that they do not have the space to elaborate, reflect, and nuance the issue of sex dolls. For instance, one of the scholars frequently quoted is Richardson, whose standpoint on sex dolls is clearly and unambigiously negative. Richardson could have been juxtaposted with Devlin, who is a professor of human-computer interaction, and whose view on sex dolls as a phenonomen is much different. Richardson has a feminist perspective, and, as Rubin observes, "much of the oppression is borne by, mediated through, and constituted within, sexuality" (1984, p. 165). Devlin (2018), on the other hand, focuses on other feminst perspectives due to her research area. Devlin compares sex dolls with sex work and argues that the different explanations as to whether women have transactional sex imply that an advanced analysis is needed to understand this phenomenon. The same goes for sex dolls, which according to Devlin do not constitute a simple, one-sided phenomenon. In the 
articles in this study, such elaborate analyses are seldom allowed space, and instead, the dolls become symbols of womanhood, all the more so because they are not individual organic women but can represent all women. Perhaps especially women who are oppressed and do not have a voice of their own. This is paradoxical in relation to the previously mentioned "color blindness" of the writers, since whiteness (among other characteristics) is presumed.

To conclude, this study confirms to a large extent Döring and Pöschl's (2019) content analysis of media representations of sex robots. Although our study differs from Döring and Pöschl with regards to theoretical perspectives and methodology, both studies demonstrate that sex dolls and sex robots are a sensitive topic that transgresses (all too) many taboos in contemporary Western society.

A practical implication of the results of this study could be an effort to open up the discourse on sex dolls in order to create a more balanced perspective on what can constitute a "good sexuality". The research results can thus be used to shed light on different discourses' effect on unequal power relations. Instead of a narrow focus on harm and sex dolls as objects to be condemned, a more balanced and open perspective can adjust the conditions of the discussion on sex dolls and include also positive effects of the use of dolls for private as well as for potential therapeutic interventions.

The need for boundaries between the organic and the synthetic, that which is worthy of protection and that which should be abhorred, is not surprising. This is why the writers discussed above always relate with a distance to the sex dolls as a phenomenon. Very rarely, even never, is the sex doll described as a part of a relation and/or as a sexual practice among others. No, instead she is a sexual aid for lonely men or men with disabilities. Not only is it a question of a social threat to the image of woman, but also what technology can do with this image. What happens if the ruling feminist theoretical framework is positioned against the sexological framework, and what can we expect of the future? In the media discourse on sex dolls a threat to existing ethics and morals emerges-with chaos awaiting.

Funding Open access funding provided by Malmö University.

\section{Compliance with Ethical Standards}

Conflict of interest The authors declare that they have no conflict of interest.

Open Access This article is licensed under a Creative Commons Attribution 4.0 International License, which permits use, sharing, adaptation, distribution and reproduction in any medium or format, as long as you give appropriate credit to the original author(s) and the source, provide a link to the Creative Commons licence, and indicate if changes were made. The images or other third party material in this article are included in the article's Creative Commons licence, unless indicated otherwise in a credit line to the material. If material is not included in the article's Creative Commons licence and your intended use is not permitted by statutory regulation or exceeds the permitted use, you will need to obtain permission directly from the copyright holder. To view a copy of this licence, visit http://creativecommons.org/licen ses/by/4.0/. 


\section{References}

Angelides, S. (2019). The fear of child sexuality: Young people, sex and agency. Chicago, London: The University of Chicago Press.

Berglund, C., Persson, O., Westerstrand, J. \& Kanakaris, Z. (2019). Det är dags att förbjuda de skadliga sexrobotarna [It's time to ban the harmful sex dolls]. Expressen. Retrieved 02 March, 2019, from Retriever Research.

Blizzard, D. (2015). Making the fantasy: Consumption, relationships, and the realdoll. In M. Larsson \& S. Johnsdotter (Eds.), Sexual fantasies: At the convergence of the cultural and the individual (pp. 57-77). New York: Peter Lang Publishers.

Corinthians 13:11, Holy Bible: King James Version.

Connell, R. (2005). Masculinities. Cambridge: Polity Press.

de Fren, A. (2009). Technofetishism and the uncanny desires of A.S.F.R. (alt.sex.fetish.robots). Science Fiction Studies, 36(3), 404-440. https://doi.org/10.5040/9781474248655.0039.

Danaher, J. (2017a). Robotic rape and robotic child sexual abuse: Should they be criminalised? Criminal Law and Philosophy, 11(1), 71-95. https://doi.org/10.1007/s11572-014-9362-x.

Danaher, J. (2017b). Should we be thinking about robot sex? In J. Danaher \& N. McArthur (Eds.), Robot sex: Social and ethical implications (pp. 3-14). Cambridge: MIT Press.

Devlin, K. (2018). Turned on: Science, sex and robots. London: Bloomsbury Sigma.

Döring, N., Mohseni, M. R., \& Walter, R. (2020). Design, use, and effects of sex dolls and sex robots: Scoping review. Journal of Medical Internet Research, 22(7), e18551. https://doi.org/10.2196/18551

Döring, N., \& Pöschl, S. (2018). Sex toys, sex dolls, sex robots: Our under-researched bed-fellows. Sexologies, 27(3), 51-55. https://doi.org/10.1016/j.sexol.2018.05.009.

Döring, N., \& Pöschl, S. (2019). Love and sex with robots: A content analysis of media representations. International Journal of Social Robotics, 11(4), 665-677. https://doi.org/10.1007/s12369-01900517-y.

Fairclough, N. (1995). Media discourse. London: Edward Arnold.

Ferguson, A. (2010). The sex doll: A history. Jefferson: McFarland \& Company.

Fjeldstad, O. (2016). Nu kan du få ligga med din favoritkändis-Här är nya sexrobotarna [Now you can sleep with your favorite celebrity-here are the new sex robots]. Expressen. Retrieved 02 March, 2019, Retriever Research.

Hansson, F. \& Grahn, L. (2016). Han var gift och hade barn-Blev kär i en sexdocka [He was married and had children-Fell in love with a sex doll]. Expressen. Retrieved 02 March, 2019, from, Retriever Research.

Haraway, D. (1985). A manifesto for cyborgs: Science, technology, and socialist feminism in the 1980's. Socialist Review, 80, 65-108. https://doi.org/10.1080/08164649.1987.9961538.

Harper, C. A., \& Lievesley, R. (2020). Sex doll ownership: An agenda for research. Current Psychiatry Reports, 22(10), 1-8. https://doi.org/10.1007/s11920-020-01177-w.

Häggström, A. (2017). Mannens sexdocka-Var intim med hustrun och lekte med barnen [Husband's sex doll—was intimate with the wife and played with the children]. Expressen. Retrieved 02 March, 2019, from, Retriever Research.

Hübinette, T., Hörnfeldt, H., Farahani, F., \& León Rosales, R. (2012). In T. Hübinette, H. Hörnfeldt, F. Farahani, \& R. León Rosales (Eds.), Om ras och vithet $i$ det samtida Sverige [About race and whiteness in contemporary Sweden]. Tumba: Mångkulturellt Centrum.

Hübinette, T., \& Arbouz, D. (2019). Introducing mixed race Sweden: A study of the (im)possibilities of being a mixed-race swede. Culture and Empathy, International Journal of Sociology, Psychology, and Cultural Studies, 2(3), 138-163. https://doi.org/10.32860/26356619/2019/2.3.0002.

Jones, E. (2019). Här skapas några av världens mest avancerade sexrobotar [Here, some of the worlds most advanced sex robots are created]. Dagens Nyheter. Retrieved 02 March, 2019, from, Retriever Research.

Kierkegaard, S. (2018). Kvinnor ska inte tillverkas i fabrik [Women shouldn't be manufactured in factories]. Aftonbladet. Retrieved 02 March, 2019, from, Retriever Research.

Knafo, D., \& Lo Bosco, R. (2017). The age of perversion. New York: Routledge.

Kulick, D. (2005). Four hundred thousand Swedish perverts. GLQ: A Journal of Lesbian and Gay Studies, 11(2), 205-235. https://doi.org/10.1215/10642684-11-2-205. 
Kätsyri, J., Förger, K., Mäkäräinen, M., \& Takala, T. (2015). A review of empirical evidence on different uncanny valley hypotheses: Support for perceptual mismatch as one road to the valley of eeriness. Frontiers in Psychology, 6, 390. https://doi.org/10.3389/fpsyg.2015.00390.

Lindgren, S. (2007). Mellan moralpanik och teknikromantik [Between moral panic and romance of technology]. In S. Lindgren \& T. Sandgren (Eds.), Unga och nätverkskulturer-mellan moralpanik och teknikromantik [Youngsters and network cultures-between moral panic and romance of technology] (pp. 7-14). Stockholm: Ungdomsstyrelsen.

Maras, M. H., \& Shapiro, L. R. (2017). Child sex dolls and robots: More than just an uncanny valley. Journal of Internet Law, 21(5), 3-21. https://search.ebscohost.com/login.aspx?direc $\mathrm{t}=$ true \&db=buh\&AN=126554072\&site $=$ ehost-live

Maier, T. (2013). Masters of sex-the Life and Times of William Masters and Virgina Johnson, the Couple Who Taught America How to Love. New York: Basic Books.

Mori, M., MacDorman, K. F., \& Kageki, N. (2012). The uncanny valley the original essay by Masahiro Mori. IEEE Robotics \& Automation Magazine, 19(2), 98-100. https://doi.org/10.1109/ MRA.2012.2192811.

Reid, J. (2012). "My Room! Private! Keep Out! This Means You!": A brief overview of the emergence of the autonomous teen bedroom in post-World War II America. The Journal of the History of Childhood and Youth, 5(3), 419-443. https://doi.org/10.1353/hcy.2012.0034.

Richardson, K. (2015). The asymmetrical 'relationship': Parallels between prostitution and the development of sex robots. SIGCAS Computers \& Society, 45(3), 290-293. https://doi.org/10.1145/28742 39.2874281 .

Rubin, G. (1984). Thinking sex: Notes for a radical theory of the politics of sexuality. In C. Vance (Ed.), Pleasure and danger (pp. 267-319). New York: Routledge.

Rubin, G. (2011). Blood under the bridge: Reflections on "Thinking Sex." GLQ: A Journal of Lesbian and Gay Studies, 17(1), 15-48. https://doi.org/10.1215/10642684-2010-015.

Smith, J. (2013). The erotic doll: A modern fetish. New Haven: Yale University Press.

Sparrman, A. (2014). Barn tecknar nakenhet—och sexualitet? [Children draw nudity—and sexuality?]. In Y. Eriksson (Ed.), Barn tecknar världen: Att förstå och tolka barns bilder [Children draw the world: To understand and interpret children's images] (pp. 47-76). Lund: Studentlitteratur.

Tapper, M. (2018). Tau och Zoe tar greppet om AI [Tau and Zoe takes the hold of AI]. Helsingborgs Dagblad. Retrieved 02 March, 2019, from, Retriever Research.

Torstensson, A. (2019). Användandet av sexdockor måste regleras [The use of sex dolls must be regulated]. Dagens Nyheter. Retrieved 02 March, 2019, from, Retriever Research.

Thomasson, J. (2019). Dessa män måste få hjälp i tid [These men need help in time]. Hela Gotland. Retrieved 02 March, 2019, from, Retriever Research.

TT. (2016). Barnsexdockor säljs till pedofiler [Child sex dolls sells to pedophiles]. Svenska Dagbladet. Retrieved 02 March, 2019, from, Retriever Research.

TT. (2018). Norrman döms för köp av sexdocka [Norwegian is convicted of buying a sex doll]. Borås Tidning. Retrieved 02 March, 2019, from, Retriever Research.

Vickhoff, A. \& Andersson, M. (2018). Nya bordellen med sexdockor kritiseras [The new brothel with sex dolls is criticized]. Kvällsposten. Retrieved 02 March, 2019, from, Retriever Research.

White, M. J. (1978). The statue syndrome: Perversion? Fantasy? Anecdote? The Journal of Sex Research, 14(4), 246-249. https://doi.org/10.1080/00224497809551011.

Wilson, M. (2018). Finländare köade till landets första bordell med sexdockor [Finns lined up for country's first brothel with sex dolls]. Nyheter24. Retrieved 02 March, 2019, from, Retriever Research.

Winnicott, D. W. (1971). Playing and reality. London: Tavistock Publications.

Winther Jørgensen, M., \& Phillips, L. (2000). Diskursanalys som teori och metod [Discourse analysis as theory and method]. Lund: Studentlitteratur.

Publisher's Note Springer Nature remains neutral with regard to jurisdictional claims in published maps and institutional affiliations. 